\title{
Protocol for seaweed decontamination to isolate unialgal cultures
}

\author{
Daniela R. P. Fernandes, ${ }^{1,2}$ Nair S. Yokoya, ${ }^{3}$ Yocie Yoneshigue- \\ Valentin $^{*, 1}$
}

${ }^{1}$ Instituto de Biologia, Departamento de Botânica, Universidade Federal do Rio de Janeiro, Brazil,

${ }^{2}$ Programa de Pós-graduação em Biotecnologia Vegetal, Decania do Centro de Ciências da Saúde, Universidade Federal do Rio de Janeiro, Brazil,

${ }^{3}$ Núcleo de Pesquisa em Ficologia, Instituto de Botânica, Brazil.

\begin{abstract}
Decontamination protocols in seaweeds are essential tools for ecophysiological studies in laboratory cultures. These protocols consist of a set of procedures and physical and chemical treatments that must be adjusted for each species. Thus, the effects of explant size and of combinations of physical treatments (brushing and cutting) and chemical treatments (sodium hypochlorite, detergent, seawater, distilled water, germanium dioxide) on the process of obtaining unialgal culture of two pigmentar morphos of Hypnea musciformis were investigated. It was found that thallus segments $50 \mathrm{~mm}$ in length, when transported from the field to the laboratory, remained healthier and were less susceptible to epiphytes than those $7 \mathrm{~mm}$ in length. The collected material had surfaces contaminated by diatoms, which were weakly attached, as well as surface contamination caused by strongly attached Sahlingia subintegra. The most efficient combination of physical and chemical treatments was explant brushing, cutting and washing with detergent. This combination eliminated the contamination by $S$. subintegra, but not all of the diatom contamination. The population of the latter was reduced by using physical treatment and by washing with detergent and distilled water and then exterminated by using germanium dioxide $(0.003 \mathrm{mg} / \mathrm{L})$. Employing this protocol, unialgal cultures of H. musciformis could be established in approximately eight to ten weeks.
\end{abstract}

\section{Article}

Received 19 Dec 2010

Accepted 17 Jan 2011

Available online 20 Apr 2011

ISSN 0102-695X doi: $10.1590 / \mathrm{S} 0102-695 X 2011005000060$

\section{Introduction}

Culture techniques for macroalgae are valuable tools in studies of ecophysiology, whether they are focused on basic research or on the investigation of products relevant to humans. Laboratory culture prevents the depletion of natural populations and also allows the selection of organisms that exhibit features of interest for specific applications, especially in the pharmaceutical and food industries (Reddy et al., 2008).

One of the major challenges encountered in establishing laboratory cultures of seaweed is maintaining them free of contaminating algae (microalgae and cyanobacteria). These organisms tend to grow faster than the seaweed, compete for nutrients and may release substances that inhibit the growth or are toxic (Berland et al., 1972). To avoid contamination of the culture and interferences in the experiment, protocols for decontamination can be developed (Xuewu \& Kloareg, 1992). These can be designed to obtain unialgal cultures; these can contain only one species of seaweed, but may be accompanied by bacteria, or can be axenic cultures, in which the only organism in culture is the seaweed without bacteria or fungi (Oliveira et al., 1995). In general, bacteria coexist harmoniously with seaweeds and may be required, depending on the culture medium used (Oliveira et al., 1995).

Thus, there is a wide range of protocols for decontamination (McCracken, 1989), using chemical treatments based on antibiotics or the potentially toxic germanium dioxide (Lewin, 1966; Markham \& Haegmeier, 1982, Evans \& Trewavas, 1991; AguirreLipperheide et al., 1995; Kawai et al., 2005), together with disinfectant solutions such as detergents and sodium hypochlorite (Bravin et al., 2006; Ramlov et al., 2009). Protocols can include physical treatments such as ultrasound or brushing (Fries, 1963; Brown, 1982; McCracken, 1989). In general, any one of these treatments alone will probably be ineffective (Oliveira et al., 1995). To ensure success, the decontamination protocol should combine various chemical, physical and/or mechanical treatments (McCracken, 1989; Xuewu \& Kloareg, 1992; Aguirre-Lipperheide \& 
Evans, 1993; Oliveira et al., 1995). The establishment of the type of protocol to be applied is directly related to the purpose of the culture.

In the present work, combinations of soft chemical and mechanical treatments were tested in order to develop a decontamination protocol for obtaining unialgal cultures of two pigmentar morphos of Hypnea musciformis (Wulfen) J.V. Lamour.

\section{Materials and Methods}

Two pigmentar morphos of Hypnea musciformis, green and brown, were collected in the municipality of Armação de Búzios, Rio de Janeiro, Brazil (22॰44'02"S - 41 $\left.{ }^{\circ} 57^{\prime} 29^{\prime \prime} \mathrm{W}\right)$.

Specimens were excised in two sizes: approximately $7 \mathrm{~mm}$ and $50 \mathrm{~mm}$ from the apical region that contains the apical cell responsible for growth. In both cases, these thallus segments were washed several times in the local seawater (previously filtered through $50 \mu \mathrm{m}$ and $10 \mu \mathrm{m}$ pore mesh filters) and were cleaned with tweezers and a brush. The penultimate wash was done with a solution containing sterile distilled water solution containing concentrated sodium sulfonate detergent $(150 \mu \mathrm{l} / \mathrm{L})$ for $30 \mathrm{~s}$, followed by a final wash with filtered local seawater. Thallus segments were transported to the laboratory in flasks with four or five segments in $200 \mathrm{~mL}$ of filtered seawater or flasks with one segment in $50 \mathrm{~mL}$ of filtered seawater. Material was transported to the laboratory in thermally insulated boxes at a temperature of $15-20^{\circ} \mathrm{C}$.

Glassware used in this protocol was sterilized (Yoneshigue-Valentin, 1990; Bravin \& YoneshigueValentin, 2002) and all instruments employed in the handling of macroalgae were sterilized in ethanol $\left(92^{\circ}\right)$; scalpels and tweezers were flamed.

During the culture, the seawater used to clean $H$. musciformis and in the preparation of culture medium, was sterilized by filtration and by heating. In the field, seawater was filtered through $50 \mu \mathrm{m}$ and $10 \mu \mathrm{m}$ pore mesh filters. In the laboratory, seawater was filtered through a cellulose membrane (Millipore $0.45 \mu \mathrm{m})$ and stored in the dark. The filtered seawater was then pasteurized by heating in an autoclave. The autoclave was turned off two minutes after reaching a boil. Seawater was maintained for $20 \mathrm{~min}$ inside the machine and then stored at $22{ }^{\circ} \mathrm{C}$. This process was repeated on two consecutive days. Distilled water was sterilized by autoclaving for $45 \mathrm{~min}$ at $120{ }^{\circ} \mathrm{C}$ and used to control the salinity of the seawater (32) and to clean segments of $H$. musciformis.

After arrival at the laboratory, segments of green and brown morphs of $H$. musciformis were submitted to physical treatment to remove the epiphytes and microalgae from the surface of the thallus. For this treatment, the surface of explants was brushed and the thallus was sectioned and grated with tweezers and scalpel to remove epiphytes like the crustose red alga (Sahlingia subintegra (Rosenvinge) Kornmann) that forms on the thallus surface near the apex. Parts of the frond that were covered by many epiphytes were excised to at most $1 / 3$ of their original size, leaving at least $7 \mathrm{~mm}$ of the thallus. Several solutions were tested for the subsequent chemical treatment. These solutions were tested during the weekly renewal of the culture medium over a period of four weeks (Table 1). All physical and chemical treatments were performed in aseptic conditions and explants were observed under a stereoscopic microscope.

Table 1. Solutions used in chemical treatment over four weeks.

\begin{tabular}{|c|c|c|c|c|}
\hline & Treatment & Concentration & Time (s) & $\begin{array}{c}\text { Washes } \\
\text { with } \\
\text { seawater }\end{array}$ \\
\hline A & $\begin{array}{l}\text { Sodium } \\
\text { Hypochlorite }\end{array}$ & $\begin{array}{c}1.01 \% \text { active } \\
\text { chlorine/L } \\
\text { of sterilized } \\
\text { seawater }\end{array}$ & 5 & three \\
\hline B & $\begin{array}{l}\text { Detergent based on } \\
\text { sulfonic acid } 5 \% \\
\text { (w/w) and sodium } \\
\text { hydroxide } 1.32 \% \\
(w / w)\end{array}$ & $\begin{array}{l}150 \mu 1 / L \text { in } \\
\text { sterilized } \\
\text { seawater }\end{array}$ & 10 & three \\
\hline C & $\begin{array}{l}\text { Sodium } \\
\text { hypochlorite } \\
\text { followed by } \\
\text { detergent }\end{array}$ & $\begin{array}{l}\text { Equal to A } \\
\text { and B }\end{array}$ & $\begin{array}{l}\text { Equal to A } \\
\text { and B }\end{array}$ & $\begin{array}{l}\text { One } \\
\text { between } \\
\text { and one } \\
\text { after the } \\
\text { solutions }\end{array}$ \\
\hline D & Sterilized seawater & 35 & $\begin{array}{l}10 \text { each } \\
\text { wash }\end{array}$ & four \\
\hline $\mathrm{E}$ & Sterilized seawater & 35 & $\begin{array}{l}10 \text { each } \\
\text { wash }\end{array}$ & eight \\
\hline
\end{tabular}

During the first week of cultivation, explants were kept in $400 \mathrm{~mL}$ Erlenmeyer flasks containing sterilized seawater, which was changed twice during this period. During the other weeks, von Stosch culture medium (Edwards, 1970) diluted to $1 / 8$ of the original concentration was used. Initially, $1 / 3$ of the volume of the culture medium in each flask was occupied by segments of $H$. musciformis. They were sectioned when the thallus volume reached $2 / 3$ of that of the culture medium. $H$. musciformis segments were maintained in stagnated culture at $30-40 \mu \mathrm{mol}$ photons $\mathrm{m}^{-2} \cdot \mathrm{s}^{-1}$, a salinity of 32 and a photoperiod of $12 \mathrm{~h}$.

As an alternative to partially successful decontaminating treatments, $10 \mathrm{~s}$ washes with detergent (150 $\mu \mathrm{L} / \mathrm{L}$ in sterile distilled water) were performed weekly, followed by $30 \mathrm{~s}$ washes in distilled water with agitation. In cases where diatoms persisted in culture, germanium dioxide solution $(0.003 \mathrm{mg} / \mathrm{L})$ (modified from 
Shea \& Choppin, 2007) was used weekly.

Several parameters were accompanied in order to verify the health of the explants. The consistency of the thallus was characterized as flaccid (when it was easily ripped), consistent (a median texture stage) and rigid (a texture similar to the field material, hard to rip). The explant colour was defined as either pale or pigmented like the specimens from the field. The efficiencies of the treatments were judged on the basis of visual examination using stereoscopic and optical inverted microscopes.

\section{Results and Discussion}

The explant size most appropriate for transportation from the field to the laboratory was tested, together with physical and chemical treatments for decontamination in the laboratory to obtain unialgal cultures. Explants about $50 \mathrm{~mm}$ in length remained healthier in culture, with intense pigmentation, and were more rigid and less susceptible to excessive proliferation of microalgae and epiphytes than those $7 \mathrm{~mm}$ in length.

Diatoms (Navicula sp., Nitzschia sp.) and Sahlingia subintegra were attached to the thallus of field specimens of pigmentar morphos of $H$. musciformis. Analyzing the thallus cross-sections of $H$. musciformis, it was observed that the epiphytic species of diatoms were weakly attached to the surface without damaging the thallus. Thus, this infection was characterized as type I (Leonardi et al., 2006) (Figure 1). However, $S$. subintegra was strongly adhered to the surface of $H$. musciformis thallus, but without invading the cortical cells, characterizing an infection of type II (Leonardi et al., 2006) (Figure 1)

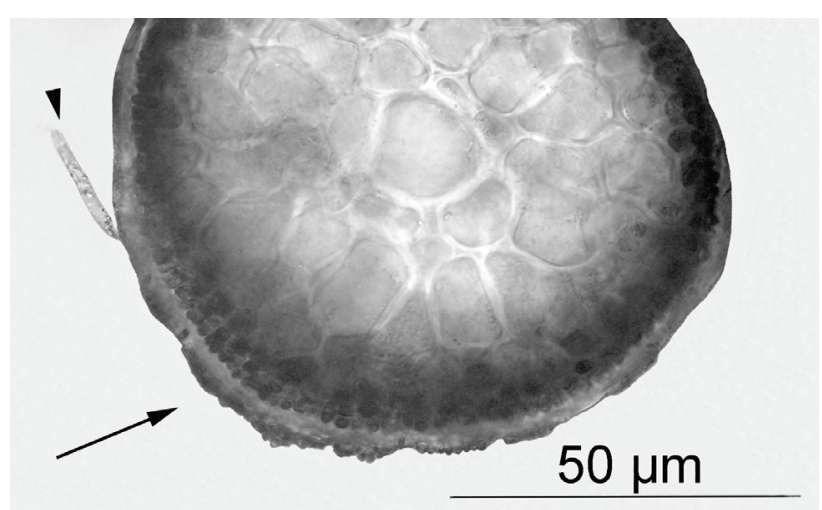

Figure 1. Cross section of the medium region of a Hypnea musciformis thallus, showing infection by epiphytes: Sahlingia subintegra (arrow) and diatom (arrow head).

During the incubation time, the brown morpho of $H$. musciformis showed little infection by diatoms and rare red crusts of Sahlingia subintegra. In comparison, the green morpho had diatoms in larger quantities and numerous red crusts ( $S$. subintegra), mainly in the basal portion of the explants. Thus, the brown morpho seems to be less susceptible to fixation of crustose epiphytes, as well as diatoms, on their surface. The combination of removal of the basal portions of the thallus, the use of physical treatment and decontamination solutions showed a range of effectiveness. The cleanup of the explants by brushing and by excising contaminated regions was a factor of great importance in obtaining unialgal cultures in a shorter period of time, but depend on the accuracy of the person who executes these procedures,

At the end of four weeks, the best decontamination treatment we found was: washing in detergent followed by detergent plus sodium hypochlorite. Despite a large reduction of pathogen contaminants, the combination of sodium hypochlorite and detergent caused a slight loss of pigmentation and a softening of the thallus. Washing only with seawater, eight and four times, failed to reduce the contamination and the explants died because of the proliferation of contaminants. Although sodium hypochlorite alone reduced the contaminants, it also caused some thallus depigmentation (pale), softening and ripping (Schenkman, 1986).

In the treatment using detergent, cultures of $H$. musciformis brown morpho showed no $S$. subintegra after the third week, while these crusts were not evident in the green morpho after the fourth week of treatment. The detergent appears to reduce the adhesion on the parts that develop during the treatment. The thallus of both pigmentar morphs remained pigmented and consistent. However, treatment with detergent was not able to eliminate the diatom contamination.

After the period of decontamination with detergent, weekly washes with distilled water for $30 \mathrm{~s}$ were initiated. Macroalgae with a parenchymatous or pseudoparenchymatous thallus resist changes in salinity (osmotic shock with distilled water) more readily than unicellular organisms (James, 1978). It the distilled water washed caused a gradual reduction in the diatoms that had resisted the previous treatment with detergent. However, even when this procedure was repeated weekly for six months, accompanied by explant excision, diatom contamination continued, despite a reduction in cell number during this experimental period. Therefore, we opted to use germanium dioxide $(0.003 \mathrm{mg} / \mathrm{L})$ to prevent diatom growth. The absence of diatoms in the culture was verified after adding this solution for two weeks. The $\mathrm{GeO}_{2}$ concentration employed was based on Shea \& Chopin (2007), who recommended the addition of 0.0004 to $0.0022 \mathrm{mg}$ of germanium dioxide per liter of seawater to prevent diatom growth without compromising the development of the microscopic phase of Laminaria saccharina (Linnaeus) J.V. Lamour in culture. However, is should be noted that experiments should be performed only one month after ending the contact of the explants with germanium 
dioxide in order to minimize any deleterious influence on the physiology of Hypnea musciformis.

In summary, we propose the following decontamination protocol: At the collection site, thallus segments of $H$. musciformis $50 \mathrm{~mm}$ in length should be washed with detergent solution in distilled water $(150 \mu \mathrm{L} / \mathrm{L})$ and rinsed in filtered seawater. In the laboratory, vigorous weekly cleaning of explants by brushing and excision of contaminated basal portions, removing at most $1 / 3$ of the total size of the explants, with a final size not less than $7 \mathrm{~mm}$ should be performed. This physical treatment should be combined with chemical treatments with sodium sulfonate detergent-sterile distilled water solution $(150 \mu \mathrm{L} / \mathrm{L})$ for $10 \mathrm{~s}$, followed by washing with pure distilled water with shaking for $30 \mathrm{~s}$; this should result in the disappearance of the crusts $S$. subintegra and reduced infection by diatoms. After a week, germanium dioxide $(0.003 \mathrm{mg} / \mathrm{L})$ should be added weekly to the culture medium for two weeks. If necessary, an interval of one week is recommended if another attempt proves necessary. Based on this protocol, unialgal cultures of Hypnea musciformis were obtained after eight to ten weeks.

\section{Acknowledgments}

The authors are grateful to CAPES for the $\mathrm{PhD}$. grant to the first author [Post-Graduate Programme in Plant Biotechnology, Federal University of Rio de Janeiro (UFRJ)] and to the Brazilian National Council for Scientific and Technological Development (CNPq, Brazil) for financial support of the second (Process number 309672/2007-4) and third authors (Process number 309929/2009-1).

\section{References}

Aguirre-Lipperheide M, Estrada-Rodríguez FJ, Evans LV 1995. Facts, problems and needs in seaweeds tissue culture: an appraisal. J Phycol 31: 677-688.

Aguirre-Lipperheide M, Evans LV 1993. A sterilization protocol for the Dictyotales (Phaeophyceae). J Phycol 29: 243 251.

Berland BR, Bonin DJ, Maestini ST 1972. Are some bacteria toxic for marine algae? Mar Bio 12: 189-193.

Bravin IC, Yoneshigue-Valentin Y 2002. Influência de fatores ambientais sobre o crescimento in vitro de Hypnea musciformis (Wulfen) Lamouroux (Rhodophyta). Rev Bras Bot 25: 469-474.

Bravin IC, Yoneshigue-Valentin Y, Yokoya NS 2006. Formação de calos e regeneração de segmentos apicais de Hypnea musciformis (Wulfen) Lamouroux (Gigartinales, Rhodophyta): obtenção de culturas axênicas e efeitos de diferentes concentrações de ágar. Rev Bras Bot 29: 175182 .

Brown L. 1982. Production of axenic cultures of algae by an osmotic method. Phycologia 21: 408-410.

Edwards P 1970. Illustrated guide to the seaweeds and sea grasses in the vicinity of Porto Aransas, Texas. Cont Mar Sci Aust 15: 1-228.

Evans LV, Trewavas AJ 1991. Is algal development controlled by plant growth substances? J Phycol 27: 322-326.

Fries L 1963. On cultivation of axenic red algae. Physiol Plant 16: 695-708

James DE 1978. Culturing Algae. Burlington and Gladstone: Carolina Biological Supply Company.

Kawai H, Motomura T, Okuda K 2005. Isolation and Purification Techniques for Macroalgae. In Andersen RA (org.) Algal culturing techniques. San Diego: Elsevier Academic Press, p. 133-144.

Lewin JC 1966. Silicon metabolism in diatoms. V. Germanium dioxide, a specific inhibitor of diatom growth. Phycologia 6: $1-12$.

Leonardi PI, Miravalles AB, Faugeron S, Flores V, Beltrán J, Correa JA 2006. Diversity, phenomenology and epidemiology of epiphytism in farmed Gracilaria chilensis (Rhodophyta) in northern Chile. Eur J Phycol 41: 247-257.

Markham JW, Hagmeier E 1982. Observations on the effects of germanium dioxide on the growth of macro-algae and diatoms. Phycologia 21: 125-130.

McCracken IR 1989. Purifying algal cultures-A review of chemical methods. Proc N S Inst Sci 38: 145-168.

Oliveira EC, Paula EJ, Plastino EM, Petti R 1995. Metodologias para cultivo no axenico de macroalgas marinas in vitro. In: Oliveira EC, Sar E (org.). Manual de Métodos Ficológicos. Concepción: Universidad de Concepción. p. 429-447.

Ramlov F, Plastino EM, Yokoya NS 2009. Efeitos do ágar no crescimento de explantes e na formação de calos em morfos pigmentares de Gracilaria domingensis (Kützing) Sonder ex Dickie (Gracilariales, Rhodophyta). Rev Bras Bot 32: 607-615.

Reddy CRK, Jha B, Fujita Y, Ohno M 2008. Seaweed micropropagation techniques and their potentials: an overview. J Appl Phycol 20: 609-617.

Shea R, Chopin T 2007. Effects of germanium dioxide, an inhibitor of diatom growth, on the microscopic laboratory cultivation stage of the kelp, Laminaria saccharina. J Appl Phycol 19: 27-32.

Schenkman RPF 1986. Cultura de Hypnea (Rhodophyta) in vitro como subsídio para estudos morfológicos, reprodutivos e taxonômicos. São Paulo, 91 p. Tese de Doutorado, Instituto de Biociências, Universidade de São Paulo.

Xuewu L, Kloareg B 1992. Explant axenisation for tissue culture in marine macroalgae. Chin J Ocean Limin 10: 268-277.

Yoneshigue-Valentin Y 1990. The life cycle of Laminaria abyssalis Joly et Oliveira Filho (Laminariaceae, Laminariales, Phaeophyta) in culture. Hydrobiologia 204/205: 461466.

\section{*Correspondence}

Yocie Yoneshigue-Valentin

Instituto de Biologia, Departamento de Botânica, Universidade Federal do Rio de Janeiro

Rua Carlos Chagas Filho, 373, Ilha do Fundão, 21941-902 Rio de Janeiro-RJ, Brazil

yocie@biologia.ufrj.br

Tel. + 552125626322 